\title{
Stage IVB Colon Cancer AJCC v7
}

National Cancer Institute

\section{Source}

National Cancer Institute. Stage IVB Colon Cancer A/CC v7. NCI Thesaurus. Code C115054.

Stage IVB includes: Any T, Any N, M1b. M1b: Metastases in more than one organ/site or the peritoneum. (AJCC 7th ed.) 